\title{
NATALIA CICHOŃ
}

Instytut Filologii Klasycznej Uniwersytetu Jagiellońskiego ul. Profesora Stanisława Łojasiewicza 6, 30-348 Kraków

Polska - Poland

\section{THE JUDGEMENT OF PARIS AS EXAMINED BY A LAWYER AND A CHRISTIAN MORALIST: DRACONTIUS' DE RAPTU HELENAE}

\begin{abstract}
Cichon Natalia, The Judgement of Paris as Examined by a Lawyer and a Christian Moralist: Dracontius' De raptu Helenae (Sąd Parysa oczami prawnika i chrześcijańskiego moralisty, czyli De raptu Helenae Drakoncjusza).

In this paper I examine Dracontius' poem De raptu Helenae to prove his unconventionality and originality in presenting a well-known myth. He analyses the story of the judgement of Paris from the legal point of view using professional, legal vocabulary. At the same time he takes into account also the moral and Christian dilemmas and thereby he finds completely new aspects and interpretations, ignored by previous poets.
\end{abstract}

Keywords: Dracontius, Late Antiquity, Paris, Helena, legal language, Latin poetry, moralism.

Est homo grande malum: legis transgressor et audax criminis inventor, scelerum reppertor et auctor (Drac. Laud. Dei 2, 360-361): this is the way Dracontius, in his Christian poem titled Laudes Dei, describes a human being. Are these words a timeless truth if he presents Paris, a protagonist of the Trojan War, in exactly the same way? Paris' deeds constitute the main subject of De raptu Helenae - the poet uses a well-known myth to find a completely new moral message, according to which the despicable act of one person may affect the fate of many innocent people, and that every crime entails inevitable punishment. Besides this, his legal education helped him to understand this myth in such an original and novel way: he presents the judgement of Paris according to the scheme of a real trial, very often by using professional, legal vocabulary.

First, it is necessary to present in short slightly more about Dracontius' life, work and beliefs to fully understand the poem I am going to analyse in this paper. Without a doubt, Dracontius is an unconventional, intriguing and original poet - he is the essence of Latin literature of Late Antiquity. When exploring his poems more closely one can discover not only many allusions to literature from earlier periods as well as his contemporary period, both Latin and Greek, epic 
and lyric, but also many different innovations, a combination of genres, styles, allegories and metaphors.

Dracontius lived in the second half of the fifth century AD in Carthage. Even under the rule of the Vandals it was a city of science and art. The barbarians were eager to be a part of the rich cultural life of the city. The continuous discourse between Late Antiquity and the classical era did not disappear under the rule of this foreign barbarian nation. It was in Carthage where the poet gained his education and worked as a lawyer and as a public orator. He had a special title: vir clarissimus, togatus fori proconsulis almae Carthaginis ${ }^{1}$. The expression togatus defines a person that wears a toga; in more popular meaning this is a Roman citizen, in the legal language this is a lawyer, an advocate. As noted by Giovanni Santini, Dracontius' powers, duties and responsibilities remain uncertain. It is very difficult to clearly state whether he worked as a judge proconsular or as an advocate, or perhaps he practised some completely different legal profession ${ }^{2}$. The poet himself mentions his legal activity in the third book of Laudes Dei, however, even that note does not explain his exact occupation: Ille [ego] qui quondam retinebam iura togatus (Laud. Dei 3, 654). But there is no doubt that he had a law degree, as is evidenced also by his vocabulary, which is closely connected to very technical language ${ }^{3}$.

One more thing is certain - the education process in Carthage was highly developed ${ }^{4}$. In the praefatio to the collection of his mythological epyllions, called Romulea $^{5}$, Dracontius praised his teacher Felicianus because, in his opinion, he 'gave back' the literature to: sancte pater, o magister, taliter canendus es, qui fugatas Africanae reddis urbi litteras (Drac. Rom. 1, 12-13). Dracontius also mentioned that Felicianus taught both Romans and barbarians in the same school, which became a place where different cultures were mixed: barbaris qui Romulidas iungis auditorio (Drac. Rom. 1, 14). This is proof of very fast

${ }^{1}$ This expression, together with the full name of Dracontius, can be found in the signature to the fifth poem of Dracontius titled Controversia de statua viri fortis in Codex Neapolitanus: Explicit controversia stanae viri fortis quam dixit in Gargilianis thermis Blossius Emilius Dracontius vir clarissimus et togatus fori proconsulis almae Karthaginis apud proconsulem Pacideium, Moussy-Camous 1985: 8.

${ }^{2}$ Santini 2006: 193.

${ }^{3}$ Besides De raptu Helenae, also Medea and Orestis Tragoedia contain legal vocabulary.

${ }^{4}$ Strzelczyk 1992: 253.

${ }^{5}$ According to the hypothesis of Fridericus Vollmer, Dracontius' epyllions and his other pagan poems together comprise the corpus Romuleorum. Against this opinion are, for example, José Manuel Díaz de Bustamante and Ettore Provana, and Jean Bouquet and Étienne Wolff agree with their critique, supporting them with their own arguments in the introductions to the editions of Dracontius' poems. In fact, it is difficult to call romuleus (which means: referring to Romulus, related to Rome and Roman mythology) every non-Christian poem by Dracontius. Friedrich de Duhn proposes for short, pagan poems by Dracontius the title Carmina minora; and Emil Bährens titles his edition Carmina profana. Cf. Bouquet-Wolff 1996: 16-24. 
assimilation between the Vandals and the Roman people that lived in Africa. It also means that the Latin language and Latin culture started to expand into other - barbarian - cultures.

The collection of Dracontius' poems, Romulea ${ }^{6}$, as mentioned above is considered by many scholars as only the school practice of a boy; they also believe that only his Christian works (Laudes Dei and Saitsfactio) are worth more careful analyses. However, it is very difficult to agree with this hypothesis. Dracontius raises many ideological issues in Romulea: behind the mythological stories are hidden serious - both moral and ethical - reflections on the measure of evil or on the nature of the gods. As regards the moral dilemmas, Dracontius can be compared to Statius or Vergil. He also wrote two quite original epithalamia. The first of them Dracontius created during his stay in prison - he asked his friends for help through the poem. Then, when he was free again, he wrote the second poem to thank his friends for helping in his release. The tragic experience in prison changed the character of his poems - it let him grow into a deeper faith and it also let him write about it. He learnt how to write as a Catholic about God and to ask important moral questions.

Dracontius, by presenting in De raptu Helenae a well-known mythological story in a new light, i.e. from the point of view of a lawyer and a moralist, proves that in ancient mythology everybody can find a message regarding the problems of his or her contemporaries. The subject of his poem is definitely epic, but the way in which he selects all of the details and characteristics of the protagonists differs from the usual epic poems. That is because the main character is nefarius, and already in the first verse of the poem he is severely judged and condemned ${ }^{7}$. What is the purpose of such an unusual beginning of a work if most of the prooemium is about the potential causes of the Trojan War? The answer may be found in Dracontius' legal education. At the very beginning he pleads Paris, but later (such as during the process in the court) he reflects upon other causes of the war and the sources of evil and, finally, at the end, he concludes that Paris is truly guilty. Could this be an attempt to defend Parys, or rather only the desire to prove his guilt? One thing is certain - according to Dracontius a one-sided moral judgment is not right. As a lawyer he knows that he should also take into consideration other possibilities ${ }^{8}$.

We should also take into account another interpretation: the fact that at the beginning the narrator resented Paris' actions has a rhetorical function - it is supposed to arouse interest in the reader as well as his or her kindness and understanding 9 . This way the author can present himself as a man who supports

\footnotetext{
${ }^{6}$ Besides the poems mentioned before and analysed here, this edition also includes Controversia de statua viri fortis (Rom. 5), Deliberativa Achillis (Rom. 9) and Medea (Rom. 10).

${ }^{7}$ Bretzigheimer 2010: 363.

${ }^{8}$ Bretzigheimer 2010: 363.

${ }^{9}$ Bretzigheimer 2010: 363.
} 
morality and ethics. Also, at the very beginning of the poem he proves that he did not use the elegiac model and that he is not going to tell a story about amor illegitimus ${ }^{10}$, but that he is going to develop an epic subject which should tell about the glorification of great heroes and their acts. The poet wants to fulfil all of the expectations posed by the poetics of Late Antiquity and to demonstrate his originality - that is why he chooses a hero that is unfair, fraudulent and contemptible; he should not be praised like an epic hero. He changes every flattering word into scorn and indignation, completely turning the scheme of the ancient epic poem. Thereby the invective he uses at the beginning of his work may be a narrative strategy - in this way he is telling us that the poem will have an important moral value.

The song begins as follows: Troiani praedonis iter raptumque Lacaenae et pastorale scelerati pectoris ausum aggrediar meliore via (vv. 1-3). In the first three verses Dracontius presents the main subject of his work, which is preadonis iter - a path followed by a traitor who has committed a pastoral act, an act worthy of a shepherd and a farmer (the poet stresses Paris' education as a shepherd many times in the poem). A journey (a road) is the subject of both the Odyssey and the Aeneid, which means it is a subject that is characteristic of the epic genre. However, Paris differs from the heroes described by Homer and Vergil in almost every respect. He is the opposite of the real epic hero and all of his acts lead to destruction - not just to destruction of himself but to that of the entire city, whereas Odysseus and Aeneas finish their journey happily ${ }^{11}$.

The expression in the third verse is unclear and not easy to interpret: aggrediar meliore via - "I will follow the better path" or "I will present this subject in a better way". What does the word melior mean in this context? By using this expression is Dracontius trying admit that he wants to emulate the previous authors that wrote about the Trojan War, namely Homer and Vergil (whom he clearly refers to in the other part of the poem)? Or perhaps this is, according to José Manuel Diaz de Bustamante, an allegory of the measure of evil brought upon Troy by Paris the traitor, which in the end transforms into good because from the fall of Troy rises the glory of Rome? ${ }^{12}$ Bernard Barwinski thinks quite the contrary: in his opinion this expression refers to the new type of composition of the poem, to a new method of understanding and presenting a myth that is already known by everybody: Dracontius returns to the sources but presents them in a completely different and original way ${ }^{13}$. Étienne Wolff also agrees with this theory - according to him the poet is suggesting that his intention is to

\footnotetext{
${ }^{10}$ Paris is not guided by love but by the desire to escape from his pastoral life. Helena is not the victim of a violent kidnapping. They both want to escape because of their desire to unite two aristocratic families that have to govern together - this was previously predicted and determined.

${ }^{11}$ Simons 2005: 223.

${ }^{12}$ Diaz de Bustamante 1978: 128.

${ }^{13}$ Barwinski 1888: 5-7.
} 
reinterpret and to rediscover the story of Paris and of the Trojan War. By writing at the very beginning of his work about a subject that was considered unimportant by his predecessors, Dracontius complies with the requirements of the poetics of epyllion, i.e. originality and a new look at the myth ${ }^{14}$.

In the following verses the poet continues the announcement of his work's subject: he would like to present Paris as an enemy of hospitality and marital rights. The protagonist, by kidnapping Helena, destroyed not only Menelaos' marriage but also his hope of having offspring (and extending his power): nam prodimus hostem hospitis et thalami populantem iura mariti, foedera coniugii, consortia blanda pudoris (vv. 3-6).

In the above verses Dracontius includes many expressions from technical, legal language. By putting together the words iura mariti (maritus applies to thalami in the same verse) the poet clearly refers to the technical term ius mariti. The entire expression thalami iura mariti is an allusion to the formula that lawyers used during debates in the court when judging people in cases of adultery. It could refer to Menelaos' marital rights as an accusation of being betrayed by his unfaithful wife, Helena ${ }^{15}$. Foedera coniugi in v. 5 also means Menelaos' rights to Helena, which were violated by Paris. Initially, foedus meant a peace treaty and Rome's friendship with another country, later in poetry it took on a different meaning - that of a love relationship or of marriage ${ }^{16}$. Another legal term in the above passus is consortium, and the most popular meaning in law is that of a common set of goods to share between the heirs after the death of the pater familias. However, in Codex Theodosianus and Codex Iustinianus consortium it is defined as marriage, and it is this meaning that was most likely used by Dracontius ${ }^{17}$.

Then the poet explains why he considers Paris' act such a contemptible crime - in fact the role of the mother is the most important in the creation of an entire

${ }^{14} \mathrm{All}$ of these hypotheses are also summarised by Simons 2005: $286 \mathrm{f}$. It is worth mentioning that in the rest of the prooemium (vv. 22-27) Dracontius admits that, as a modest storyteller, he brings together parts of the myth despised by Homer and Vergil. He uses a metaphor - he is like the foxes that get only the leftovers after the feast of the lions. A sated animal would despise all the leftovers, however, for foxes they mean a real feast. In these words one can find Dracontius' suggestion that the great epic poets skip seemingly insignificant subjects and that for other poets, the less famous and less talented, these subjects may constitute a basis to write a poem. And perhaps this allows them to take the previously mentioned meliore via, i.e. the other, original path (this means that Dracontius and the other not-great poets do not imitate those great ones). It is also worth mentioning another interpretation: the lions may be an allusion to Rome before Late Antiquity (the time of the lions), and the leftovers eaten by the foxes are just the crumbs of past splendour - and only these crumbs are left for the contemporary poets. Therefore, Dracontius writes his poems in the shadow of a past glory, aware of the fact that culture, despite many rapid changes, is still based on tradition.

${ }^{15}$ Santini 2006: $33 \mathrm{f}$.

${ }^{16}$ Santini 2006: 34.

${ }^{17}$ Santini 2006: 35 . 
tribe: nam totum de matre venit, de matre creatur quod membratur homo; pater est fons auctor origo, sed nihil est <sine> matre pater (vv. 7-9). With these words Dracontius admits that he is opposed to some of the ancient opinions regarding procreation. Many physiologists thought that in conception men and women were equal and that their role had the same level of importance (e.g. Anaxagoras, Hippocrates, Lucretius, Isidore, Lactantius $)^{18}$. On the other hand, Aristotle claimed that a man's semen is the basis in the creation of descendants, but it is the woman who constitutes the material: her interior is a kind of nest ${ }^{19}$. Dracontius is very close to this theory: in his opinion the father is the source and the beginning, but he is nothing without the mother. This allows us to understand one of the reasons why Dracontius calls Paris "a traitor". Paris, by kidnapping Menelaos' wife, not only disgraced all the rights but also took away from him the possibility of having a descendant; she deprived him of his role as the source of a child - an extension of the family. Without a wife he is nothing.

This is also a legal discourse that is characteristic of Dracontius' poetry and refers to his profession as a lawyer - Paris disgraced a fair and good motherhood, and only such a fair and marital (legal) motherhood is right and important. In addition, the relationship between mother and father and their offspring as shown by the poet was presented in the law in the same way. Also, in his words one can see the influence of the Christian faith. This analysis makes Paris' act unforgivable - there is no excuse for what he did. One can clearly notice that the poet is trying to draw attention to the global dimension of misery and misfortune - since everything comes from the mother and she plays the most important role, this desecration of her role is the largest crime and it brings evil to the entire world and to every person. This awareness of evil as presented by the poet allows the reader to understand how much cruelty hides in the story described in Dracontius' work.

The focus on Paris at the very beginning of the song indicates that he is going to be the main protagonist and, at the same time, because of the word that Dracontius chooses to describe him - a traitor - he is the main cause of evil. The key-word is praedo in the first verse of the song. The poet finds two aspects of Paris' guilt: he disgraced the marital rights and disrespected the rights of hospitality. Already in the first lines one can see how Dracontius emphasises the sacrilegious and scandalous behavior of Paris, calling him praedo (v. 1), raptor (v. 11) and adulter (v. 11). But the most important argument that forces the poet to consider Paris in such a negative manner is the pastorale ausum (v. 2) that haunts the protagonist throughout the entire song. The term pastor defines Paris

\footnotetext{
${ }^{18}$ Roswitha Simons finds a reference to a doctrine developed by Hippocrates that she calls Zwei-Samen-Lehre, which means "the theory of two seeds" - to fertilise one needs the seed of both the man and the woman. Simons 2005: 224.

${ }^{19}$ Simons 2005: 224.
} 
during all of his transformations and during every event - it dominates over every one of his acts ${ }^{20}$.

Dracontius, throughout the entire song, repeatedly refers to fornication and to the violation of marriage, calling Paris an adulterer or making allusions to it through an interpretation of his acts and other events. Although he does not use technical legal vocabulary, he clearly refers to it when judging the characters' deeds - not only according to the criterion of Christian principles but also according to the legal rules. Later, in v. 655 , the poet clearly states that Paris' act is crimen adulteri - the crime of an adulterer. Responsibility for the crime of adultery is assigned to Paris, while in the real world in a court usually the accused person was a woman. However, this expression may be understood in two ways - as a crime of an adulterer (and this is a very rare translation) or as an accusation of committed adultery of the wife against her husband ${ }^{21}$. To sum up - while showing Paris as an adulter seems to be well known in the literature

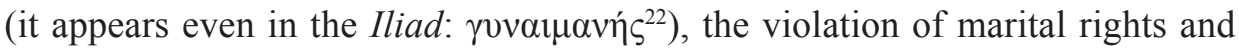
the negligence of hospitality as described by Dracontius are both definitely less traditional ${ }^{23}$.

The following lines of the poem relate to the moment when Paris has to choose the most beautiful goddess. Dracontius presents this scene as a real trial in which the shepherd is the judge and the goddesses play the role of parties in the $\operatorname{case}^{24}$.

Caelicolum praetor iam sederat arbiter Idae:

Iam gremium caespes, iam surgens herbida tellus

Stabat et aetherium fuerant herbosa tribunal.

Solverat Iliacus ceali vadimonia pastor

Et litem facit ipse suam: laudata recedit

Contempta Iunone Venus. Tunc virgo decore

Victa dolet, nam tristis abit: heu nescia mens est,

Quae mala circumstent ausum dare iura Minervae.

Iudicis Idaei pretio sententia fertur. (vv. 31-38)

First, the judge comes into the courtroom and takes a place in the bench (v. 31), then the poet gives a description of the place where the trial takes place (vv. 32-33). Then there is the actual judgement of Paris (v. 35) and the parties that have lost leave the courtroom (vv. 35-37). The above description is full of legal vocabulary, e.g. arbiter, tribunal, lis, ius, vadimonium, litem suam facere, dare iura alicui, iudex and sententiam ferre.

\footnotetext{
${ }^{20}$ Simons 2005: 223.

${ }^{21}$ Santini 2006: 33.

${ }^{22} \mathrm{Hom}$. Iliad III 39 and XIII 768.

${ }^{23}$ Santini 2006: $32 \mathrm{f}$.

${ }^{24}$ Santini 2006: 62.
} 
The natural environment - the top of the mountain covered with grass turns into a courtroom. Paris, called the leader and the judge, is a member of the tribunal: the expression sedere could be used in a legal context, it may in fact mean that he sits on the bench of judges (sella). Moreover, the word gremium in the legal language can be translated as the chair of a consul or judge, which is in the works of Plinius and Cassiodorus ${ }^{25}$. The term vadimonium in v. 34 means the promise to appear in a court within the prescribed time limits. Dracontius puts this word together with caeli, which may be translated as a promise made by heaven (goddesses) or as a promise made in heaven. Successively, the verb solvere, which basically means 'to keep', 'to preserve', can in the legal context be understood as 'to violate' or 'to disturb'. Wolff proposes to take into consideration the second meaning, assuming at the same time that vadimonium means a promise of honesty which could not be kept by Paris ${ }^{26}$. The French scholar also reflects upon another interpretation, according to which vadimonium would be used by the poet as summa vadimonii, which means 'an amount of money' (a deposit) left by the person that has to appear at a trial as a warranty of coming on the determined day. Assuming this interpretation as the proper one, we should translate solvere as 'giving the money (the deposit) back'. Then this whole expression would mean that the shepherd gave back the deposit delivered to him from heaven, which constituted a sign to start the trial2 ${ }^{27}$.

In v. 35 Dracontius presents Paris as a corrupted judge - in the legal language the expression litem suam facere means a situation in which the judgement is not impartial and fair ${ }^{28}$. Another expression from the legal language is dare iura alicui (v. 38), which means 'to pass a sentence (to give a judgement) against someone' or just 'to judge someone'29. In Dracontius' poem Paris opposes Minerva and he is not aware of the consequences of his acts. But verse 30 directly refers to the corruption of Paris as a judge: pretium probably means an amount of money used by a client to corrupt a judge and, besides that, it is commonly used not only in the legal context but also generally in Latin literature to define every corruption committed with money ${ }^{30}$.

Worth explaining are also the words $\operatorname{lis}^{31}$ (v. 35) and iurgia ${ }^{32}$ (v. 66), both referring to the argument between the goddesses and to the judgement of Paris. In the classic era, iurgium meant a legal dispute concerning a not very important

${ }^{25}$ Santini 2006: 92.

${ }^{26}$ Wolff 1987: 46.

${ }^{27}$ Wolff 1987: 46.

${ }^{28}$ Santini 2006: 94.

${ }^{29}$ Santini 2006: 94.

${ }^{30}$ Santini 2006: 95.

${ }^{31}$ Drac. Rom. 8, 35: soluerat Iliacus caeli uadimonia pastor et litem facit ipse suam.

${ }^{32}$ Drac. Rom. 66-68: sordent arva viro post iurgia tanta dearum, Pergama sola placent et moenia quaerere Troiae mens et fata iubent. 
reason during which the arbiter spoke out. Lis also meant a dispute, but a much more grave and important one in which the judgement was given by the iudex. In the postclassical era this division was not so clear anymore - poets and lawyers alike started to use both expressions to name any trial in the court. But Dracontius seems to be more traditional - he uses the word lis to describe the trial (which could mean a serious dispute that needs the judgement of a judge), while iurgium is used in the context of just an argument, a fight. This probably means that Dracontius used both expressions in the meaning originating in the legal language in the classical period ${ }^{33}$.

Dracontius dedicates the last part of the poem to a description of the tragic consequences of the Trojan War. It is a speech full of emotions in which the poet shows all the cruelty that - because of Paris - touches individuals, families, nations, and even women, children and great heroes such as Achilles and Aiax:

[...] nec solus pastor habetur

Ex hac lite reus: damnantur morte parentes,

Damnantur fratres, et quisquis in urbe propinquus

Aut cognatus errat, cunctos mors explicat una.

Atque utinam infelix urbs tantum morte periret!

Damnantur gentes, damnatur Graecia sollers (vv. 40-45).

The theme of punishment, related closely with the theme of judgement, is included by Dracontius in many of his works - both pagan and Christian poems. However, he analyses this problem in the most detailed and attentive way in $D e$ raptu Helenae. Punishment reaches Paris right after the corrupted judgement and it is followed by many tragic consequences, not only for Paris himself but also for many Trojans and Greeks - both nations start fighting because of Paris and his inconsiderate and selfish act. The expression used by Dracontius to describe Paris - reus - is very common among Christian writers and poets and means 'guilty'. Dracontius perfectly creates the atmosphere of fear and terror by using the word damnare multiple times (v. 40, 41, 42, twice in v. 45 and again in v. 47). The term also comes from legal language. Then the poet reflects on the possible reasons of the war - thanks to his legal education he is aware that there may be more than only one reason. As a lawyer he tries to find the proper explanation, the real version of events, just as during the trial. He takes into consideration the possibility that not only the gods but also people may be responsible for the Trojan War:

Pro matris thalamo poenas dependit Achilles

(unde haec causa fuit), forsan Telamonius

$\operatorname{Aiax}^{34}$ sternitur invictus, quod mater reddita non est

Hesione Priamo [...] $]^{35}$ (vv. 49-52).

\footnotetext{
${ }^{33}$ Santini 2006: 95.

${ }^{34}$ Aiax - the son of Telamon and Hesione.

${ }^{35} \mathrm{Haec}$ causa is related to the judgement of Paris, not to the entire war.
} 
Dracontius, when writing about Achilles who atoned for his mother's wedding, refers to Peleus' and Thetis' famous wedding and the story of Eris, the Greek goddess of chaos and discord. She brought to the wedding an apple which was intended for the most beautiful goddess. It caused a disagreement and a fight and - as a result - the judgement of Paris. But this is not the only reason for the Trojan War as taken into consideration by Dracontius. People may also be responsible for the war. He uses the word forsan ('maybe'), which means that the poet does not choose which reason seems more possible or more important. Perhaps the reason for the death of Ajax (i.e. the reason for the Trojan War) was the fact that Priam did not receive his sister Hesione back $^{36}$. In Dracontius' work the story of Hesione is one of the most important themes, right next to the story of the rape of Helen.

Dracontius analyses in his work circumstances that are quite rare and original for the legal world. The situation he shows is so unique because the end of this marriage is not the consequence of the betrayal of a spouse (which was the most common reason for a divorce). In this case the marriage has to be cancelled because the couple got married in an unfair and illegal manner. But not only the reason is different - also the person that demands the divorce is unusual. Here it is not the spouse but the wife's brother - and in this particular case it is Priam, Hesione's brother ${ }^{37}$. The envoys that are sent by Priam to Salamina ask Telamon to give Hesione back to them because he took her and married her illegally. Also, this way Telamon gave her power over his own country - he made his slave the queen of Salamina. It is not difficult to notice a paradox: Hesione as Telamon's wife rules Salamina, i.e. over Argives, which is a nation that defeated her country. This means that the Greek people did not gain a slave in this war, but neither was she even a real queen. How can the captive be the queen of the winning country? She cannot be a slave anymore but she cannot be a queen either. However, Telamon thinks that he cannot meet the demands of the Trojans, i.e. the demands of a nation defeated in the war.

After this episode Priam makes Paris a leader of the expedition and tells him that he should do something brave: he asks him to bring back his sister Hesione who was kidnapped by Telamon. The reward for Paris would be marriage: Priam promises to Paris that Venus will give him a beautiful wife. During the trip to Salamina a storm breaks out at sea. Only Aeneas, Antenor and Polydamas arrive in Salamina - Paris alone finds himself on Cyprus as a castaway. It is the place where he will later meet Helena in the castle, in the absence of Menelaos.

It is worth examining some fragments of the episode as mentioned above - the expedition sent by Priam to Salamina and their talk with King Telamon:

\footnotetext{
${ }^{36}$ Hesione was the daughter of Laomedon. After the war between him and Heracles, Hesione was taken to Salamina with Heracles' ally - Telamon - and they got married against her will.

${ }^{37}$ Santini 2006: 45.
} 
because of the legal language it resembles a real debate in a court. When the ambassadors ask Telamon to give Hesione back to them he gets angry and says that they want to destroy a pure and good marriage: conubium regni, thalami consortia casti scindere poscebant (vv. 288-289). After that Telamon asks rhetorically, still full of anger: who dares to tell the king or any other husband to cancel a marriage:

Conubium rescinde tuum, rumpatur honesto

foedere iuncta domus, thalami damnentur amantum,

festivas extingue faces? [...] (vv. 306-308)

Both citations contain not only poetic but also legal language: consortium (v. 288), conubium (vv. 288 and 306), scindere (v. 289), rescindere (v. 306). The expression conubium means, literally, the ability to get married in a legal way, but Dracontius most likely uses this word in the more common meaning - just as 'marriage' - which is very popular in Latin literature ${ }^{38}$. Then the most common meaning of the verb scindere in the legal language is the division of inherited assets, be it property or money; rescindere means the cancellation of a testament, verdict or commitment. Neither verb was ever used (or we do not possess any proof of such use) in the context of divorce, which means that Dracontius uses them in an original way by combining them with conubium ${ }^{39}$. He borrows the words from the legal language but he does not take them literally - he uses less common meanings.

Continuing his speech, Telamon refers in some way to the paradox that was mentioned before and asks: why should the winner obey the law of the defeated nation: quando tamen victor victi sub lege tenetur? (v. 310). He puts the right on his side by saying that, according to the law, he does not have to give back Hesione because he has won the war. He does not have to listen to the Trojans and their demands. He adds:

\footnotetext{
Post ignes reparata meos, si pendit amorem

Germanae rex ipse suae, pro dote sorori

Vel regni pars iusta detur, ne vindicet Aiax

Quod matri donasset avus, si Troia maneret. (vv. 312-315)
}

When talking about pars iusta due the king, Telamon is referring to the tradition of giving the dowry by the father (in this case it is the brother because the father is dead) when a daughter gets married. By analysing the above lines we can conclude that Priam - according to the law - is obliged to give Telamon a part of the kingdom as a dowry because it is not completely destroyed. Besides, Telamon threatens the ambassadors that his son Ajax can take the proper part of

\footnotetext{
${ }^{38}$ Santini 2006: 46.

${ }^{39}$ Santini 2006: 46.
} 
the dowry by force of arms. But the fact that Telamon asks them to give him the dowry is in fact illegal because he married Hesione without the obligatory and necessary acceptance of her father. She was kidnapped and taken to Salamina against her will and her father was killed during the war by Telamon's allies.

The expression pars iusta does not have its origin directly in the legal language, but it may be a copy of the legal words pars legitima, which was a common expression to specify the part of an amount of a dowry or money given to someone in a testament. The verb vindicare means to illegally claim someone's property or to take someone's goods illegally ${ }^{40}$. Therefore, we can conclude that the above-mentioned pars iusta is some kind of compensation to the husband to reduce his expectations of accession to the throne. Giving a part of Priam's kingdom as a dowry to Telamon would be compensation as money or property that he did not get right after he married Hesione ${ }^{41}$.

Only superficially is the passus about the expedition to Salamina not related to the subject of the poem. It consists as a part of Dracontius' considerations as mentioned in the poem about the possible reasons for the Trojan War: is there fault only in the gods or also in people? Also, it is characteristic of the style of Late Antiquity - the apparent chaos and accumulation of unrelated topics comes in the end to a logical and coherent whole. Directly after this episode Paris finally appears at Cyprus. Amor - upon the order of Venus - makes him fall in love with Helena ${ }^{42}$. Helena tells him that their fate has already been predicted and that she is supposed to marry another man. There is no kidnapping - fatum tells them to be together. They commit adultery together and in full awareness that is why the Greeks want to take revenge so badly ${ }^{43}$.

Shortly after they arrive in Troy the wedding starts and, thereby, also the carmen pastorale, the pastoral epithalamium ${ }^{44}$. But from the very first verse the reader knows that this is a very original epithalamium - it is not a happy song because the pastor comes with his future wife cum sorte sinistra (v. 638), which means: with an unhappy, inauspicious fate. Louder than the wedding song is the sound of the trumpet of war. Dracontius leaves the last words of the poem in a mood of horror. Both the destruction and death of people will be sine crimine mortis (v. 650), which means they did not commit a crime which would deserve the death penalty, but this is their punishment for Paris' crime. In the last sentence of De raptu Helenae, Dracontius includes the main concept of the entire poem: crimen adulterii

${ }^{40}$ Santini 2006: 48.

${ }^{41}$ Santini 2006: 49.

${ }^{42}$ It is worth mentioning that five motifs bring to mind the poetics of the antique romance: the first meeting of Paris and Helena in the temple, love at first sight, the unusual beauty of the lovers, the storm at sea, Menelaos and his servants chasing the lovers and disturbing them in their fulfilment of their plan.

${ }^{43}$ Bretzigheimer 2010: 397.

${ }^{44}$ Wilson 1943: 39. 
talis vindicta sequatur (v. 655). It is punishment for all people because of Paris' crime. His act also comprises the main subject of the poem - the crime is the starting point to give every moral judgement, to draw conclusions and to provide the reader with a moral message. Even in the poem the poet indicates that the subject of the poem - despite the title - is actually not the rape of Helen but Paris' act and its consequences. This means that Dracontius not only tells a mythological story but can also find a moral message for his readers.

During the entire poem Dracontius analyses Paris' deeds as a moraliser - not only in the Christian faith but also in the pagan one, according to the moral rules known from mythology. One of the most important moralising elements in this poem is the fact that Dracontius tries to show all of the cruelty brought by the war, which does not save even women and children, and decimates entire nations, brings suffering and pain - both physical and psychological. Dracontius asks: sic dolor exurgit divum, sic ira polorum saevit et errantes talis vindicta coercet? (vv. 55-56). This rhetorical question has a very important rhetoric function: Dracontius thinks that the divine punishment is disproportionate to the human acts and - besides that - when the gods take revenge on people who do evil things the punishment befalls innocent people as well. The person doing evil things is Paris; he is a deceiver and a bandit. However, Dracontius' opinion is not unilateral and thoughtless - as a real judge he shows, or suggests, the motives behind Paris' actions. He is led not by a criminal and evil love but by the desire for fame. He wants to prove that he is not a simple shepherd, yet the royal symbols and his status iudex dearum are not enough for him - he still has a feeling of inferiority, he feels inadequate because of his previous life when he was a pastor. That is why he offers himself as a leader of the delegation to Salamina, as he believes that thanks to brave acts far from his homeland he can prove his royal dignity. However, during the storm at sea he loses hope and reminisces about the peaceful and safe life of a shepherd. Again, Paris is an example of an anti-hero who lives in a tragic irony: he complains of the difficult life of kings and commanders who are exposed to war and death but, at the same time, unconsciously, through every action he seeks war and death for a large number of people ${ }^{45}$.

What is the most important moral message to be posed by Dracontius? He teaches and instructs not only through his Christian faith - he is also a moralist because as a poet he has the sense of a mission to teach people what is right and what is evil (in the era of a crisis this was characteristic of poets). He tells the universal truth that the contemptible act of one person can affect many innocent people (how similar is it to the Christian concept of original sin?). But Dracontius considers Paris' act contemptible not only because of his faith and his poetic 'mission' - from the legal point of view Paris is most of all an adulterer who deprives the legal husband of the hope of having offspring. To sum up: Dracontius,

\footnotetext{
${ }^{45}$ Betzigheimer 2010: $390 \mathrm{f}$.
} 
by rediscovering the common myth of Paris, found a completely new way to understand this story - he combined three different moral judgements: that of a pagan poet with a mission, that of a Christian and that of a lawyer.

\title{
BIBLIOGRAPHY
}

\section{Primary sources}

Blossius Aemilius Dracontius, Euvres, t. I, ed. by C. Moussy et C. Camus, Paris 1985. Blossius Aemilius Dracontius, Euvres, t. III, ed. by J. Bouquet et É. Wolff, Paris 1996.

Secondary sources and commentaries

Barwinski 1888: B. Barwinski, Quaestiones ad Dracontium et Orestis Tragoediam Pertinentes. Quaestio II: De Rerum Mythicarum Tractatione, Gottingae 1888.

Bretzigheimer 2010: G. Bretzigheimer, Dracontius' Konzeption des Kleinepos De raptu Helenae (Romul. 8), "Rheinisches Museum für Philologie” 153, 2010.

Diaz de Bustamante 1978: J.M. Diaz de Bustamante, Draconcio y sus Carmina Profana. Estudio biográfico, introduction y edición critica, Santiago de Compostela 1978.

Santini 2006: G. Santini, Inter iura poeta: ricerce sull lessico giuridico in Draconzio, Roma 2006. Simons 2005: R. Simons, Dracontius und der Mythos. Christliche Weltsicht und pagane Kultur in der ausgehenden Spätantike, München-Leipzig 2005.

Strzelczyk 1992: J. Strzelczyk, Wandalowie i ich afrykańskie państwo, Warszawa 1992.

Wilson 1943: E.F. Wilson, Pastoral and Epithalamium in Latin Literature, "Speculum" 1, 1943.

Wolff 1987: É. Wolff, Recherches sur les epyllia de Dracontius, Paris 1987.

\section{THE JUDGEMENT OF PARIS AS EXAMINED BY A LAWYER AND A CHRISTIAN MORALIST: DRACONTIUS' DE RAPTU HELENAE}

\author{
Sum mary
}

In the first part of my paper I introduce in short Dracontius' work, life and beliefs, the character of the literature in Late Antiquity and the cultural background of Carthage in the fifth century $\mathrm{AD}$, which is necessary to fully understand his poem I analyse later.

In the next part the reader is informed about the general topic and the character of De raptu Helenae. Afterwards I analyse the beginning of the poem and I propose different interpretations of this quite unclear Dracontius' praefatio. Next, in the main part, I examine all of the parts of the poem which contain legal vocabulary - the two most important parts are the judgement of Paris presented as a trail in a real court and the legation of Trojans to Salamina.

In addition to that, I find another interpretation from the other point of view - Dracontius interprets the story of Paris also as a Christian moralist and as a poet who has the sense of a mission to teach his readers what is right and what is evil.

In the final part I summarize Dracontius' way of thinking and both - legal and moral - ways he sees Paris. I also find the main moral message the poet poses in the analysed poem: he proves that Paris is guilty because, from the moral and the legal point of view, he is and adulterer who deprives Menelaos, the legal husband, of the hope of having offspring with Helena. Then, in the end of his poem, Dracontius tells the readers the universal truth: the contemptible act of one person can affect many innocent people and this is the most evil act. 